\title{
Evaluation of a dinoflagellate bloom in a perennial endorheic Mediterranean pond
}

\author{
Andrea Francesca Bellia* \& Sandro Lanfranco \\ Department of Biology, University of Malta, Msida, Malta \\ ${ }^{*}$ Corresponding author, e-mail: andrea-francesca.bellia.17@um.edu.mt
}

\begin{abstract}
This study is the first to describe a dense dinoflagellate bloom from an inland water body in the Maltese Islands. The bloom in the perennial pond at L-Ghadira ta' Sarraflu, in Gozo, Malta was first noted towards the end of April 2020 and was investigated in May 2020. Microscopic analysis indicated a unialgal bloom comprised predominantly of Peridinium cf. cinctum (O.F. Müller) Ehrenberg (Dinoflagellata Dinophyceae Peridiniaceae) at a mean density of ca. 358118 \pm 165227 cells $\mathrm{mL}-1$. Five water quality parameters $(\mathrm{pH}$, oxidation-reduction potential, dissolved oxygen concentration, electrical conductivity and temperature) were measured to provide a preliminary assessment against which future studies could compare. The absence of any long-term abiotic data from the pool precludes any definite causes of the bloom from being identified and highlights the necessity of such a programme.
\end{abstract}

KEY WORDS brackish pond; inland waters; Maltese Islands; Peridinium.

Received 30.08.2020; accepted 01.12.2020; published online 23.12.2020

\section{INTRODUCTION}

Algal blooms, defined as episodes during which the density of phytoplankton increases by several orders of magnitude relative to background levels, are a potential occurrence in enclosed aquatic systems. Although many groups of algae are known to form blooms (Smayda, 1997), some of the best characterised are those formed by dinoflagellates (Chromista Dinophyceae). The potential causes of blooms are multiple and probably interactional, and include nutrient spikes, thermal instability, reduced water movement and ecosystem imbalance (Hughes et al., 1999). Dinoflagellate blooms are frequently the basis of a Harmful Algal Bloom (HAB) although this is more often the case in the marine environment as most dinoflagellate blooms in freshwater are benign (Carty \& Parrow, 2015). Given that dinoflagellates are generally situated towards the base of food webs, an understanding of the underlying causal mechanism of a bloom would provide a deeper understanding of the role of bottom-up control in ecosystems in which they occur (Thompson et al., 2008).

The present work describes a dinoflagellate bloom that occurred in the perennial rain-fed pond at L-Ghadira ta' Sarraflu, in western Gozo, Maltese Islands. The study was initially commissioned from one of the authors (SL) by the Environment and Resources Authority (ERA) and is now part of a longterm monitoring programme to anticipate such blooms and determine the cause of their formation. To the authors' knowledge, there are no published records of dinoflagellate blooms from inland waters of the Maltese Islands, although this in itself is probably a reflection of the dearth of such wetlands. Unpublished records of dinoflagellate-dominated 
blooms in coastal or open marine conditions do exist but are generally descriptions of isolated events without any long-term context (Lanfranco et al., 2018). As such, the present work represents the first published characterisation of a dinoflagellate bloom in an inland wetland in the Maltese Islands.

\section{MATERIAL AND METHODS}

\section{Study area}

L-Ghadira ta' Sarraflu (henceforth referred to as 'SRF') is situated in western Gozo (Fig. 1) and is one of only two perennial lentic wetlands in the Maltese Islands.

The pond margin is approximately circular, with primary and secondary axes measuring $40 \mathrm{~m}$ and $34 \mathrm{~m}$ respectively, covering an approximate surface area of $1075 \mathrm{~m}^{2}$. The maximum water depth reaches ca. $3 \mathrm{~m}$ and is limited by the presence of two artificial outflows that drain the pond. In the absence of local geological or hydrological configurations to support the formation of a natural pond of these dimensions, anecdotal evidence suggests that the pond is, at least in part, man-made, and that it has increased in size over the past ca. 50 years.

\section{Field methods}

The study was based on a field visit to SRF on Saturday, $9^{\text {th }}$ May 2020, approximately ten days after the discolouration event was first noted. The water body was surveyed to identify any anomalous characteristics relative to those observed during the authors' previous visits to the site. Upon visual inspection, a relatively clumped and static dark-brown discoloration of the water column was immediately evident. Agitation of the water surface by waterfowl led to the emergence of fresh clumps of discoloured water from deeper parts of the water column. The pond and its margins were subsequently visualised from the air using a drone flying at approximately $65 \mathrm{~m}$ above the water surface and a photograph encompassing the whole pond was taken (Fig. 2).

Figure 2 was subsequently processed into a pseudocolour image (PCI) using the method described by Bellia \& Lanfranco (2019). Image processing was carried out using the $k$-clustering segmentation algorithm with a $k$ value of 6 in ImageJ v.1.53c (Schneider et al., 2012) to show the spatial extent of the discolouration (Fig. 3).

Five physicochemical properties of pond water

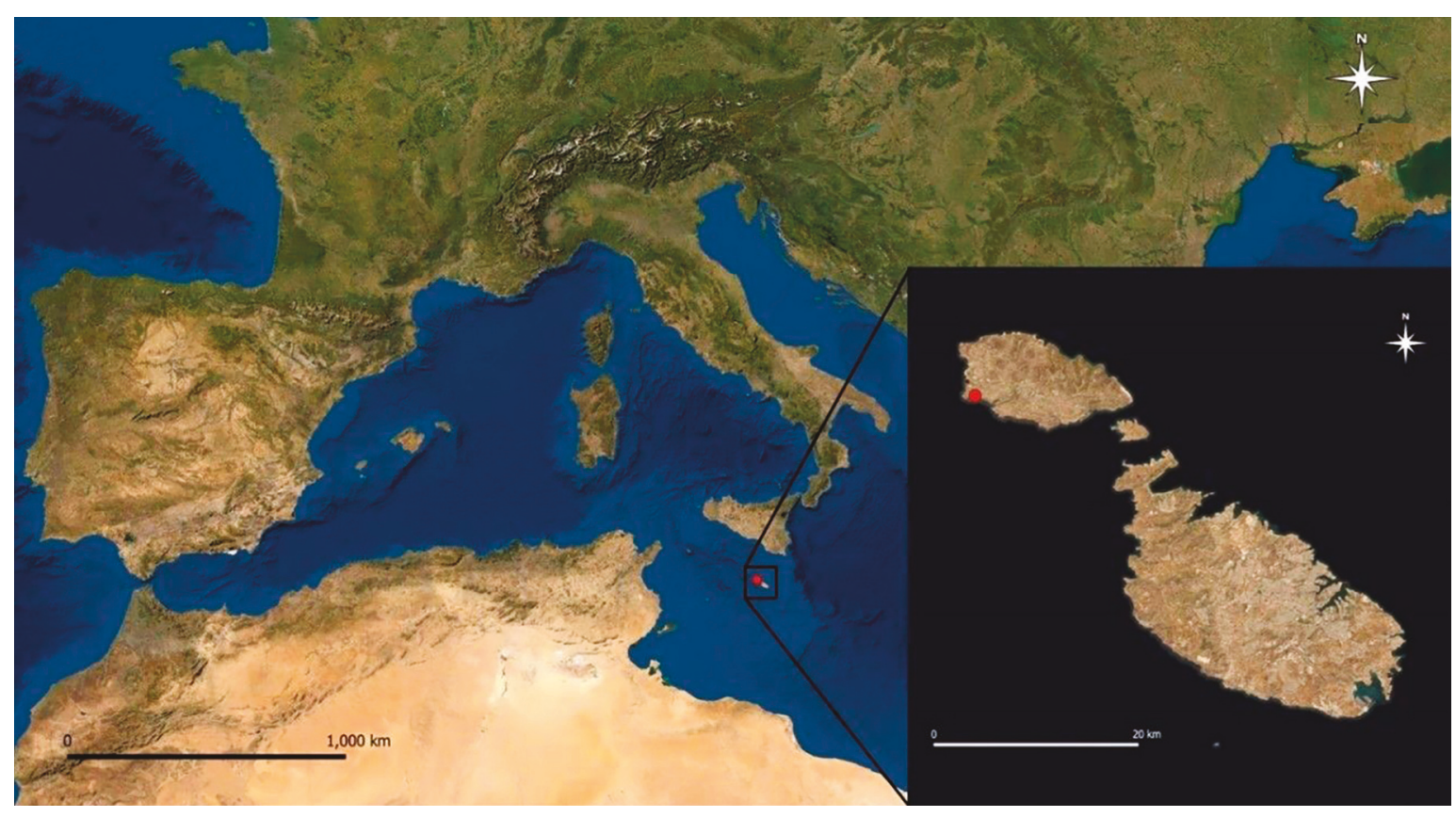

Figure 1. Geographical location of the Maltese Islands in the Mediterranean context, with L-Ghadira ta' Sarraflu (SRF) (Latitude: N $36.0366667^{\circ}$, Longitude: E $14.1991667^{\circ}$ ) indicated by a red dot. Scale bars to the bottom left and North at the top right of each map. Base map obtained from ESRI Satellite (QGIS 3.12.0 'București'). 
were measured in situ using a calibrated Hanna Instruments HI98914 multiparameter meter. The properties measured were electrical conductivity (EC) in $\mu \mathrm{S} \mathrm{cm}^{-1}, p H$, oxidation-reduction potential (ORP) in $\mathrm{mV}$, water temperature in ${ }^{\circ} \mathrm{C}$ and dissolved oxygen concentration (DO) in $\mathrm{mg} \mathrm{L}^{-1}$.

Thirteen independent measurements were taken along the accessible margins of the pond by immersing the probe just below the water surface. The instrument readout was given time to stabilise, after which the measurement was logged automatically.

Results were subsequently compared with archive data from rain-fed water bodies in the Maltese Islands, characterised as 'coastal' or 'inland' according to their geographic location. Archive data were collected by the authors during the same wet season using the same instrument. Replicate water samples were then collected from four accessible sampling points along the pond's margins using a plankton net (mesh size: $10 \mu \mathrm{m})$ with a $100 \mathrm{~mL}$ sample bottle. The plankton net was 'swept' just below the water surface for a standard length of approximately one metre. Five such sweeps were carried out at each sampling point. The water collected from each set of five sweeps was then transferred to a separate 1L sample bottle for each sampling point. Two more 1L bottles were filled with water through direct immersion. Following collection, the samples were stored in cool, dark conditions and promptly transported to the laboratory for microscopic analysis.

\section{Laboratory methods}

Microscopic analysis of the pond water started approximately three hours after collection of the samples to minimise any changes to the phytoplankton content of the samples. Phytoplankton were identified on the basis of their morphological characteristics, dimensions, and patterns of movement. The principal sources used for identification were Carty (2014), Bellinger \& Sigee (2015), Carty \& Parrow (2015), Moestrup \& Calado (2018), and Kretschmann (2020).

The first stage of analysis involved the microscopic observation of pond water at x100 magnification. This was done to visualise any biota present in the living state, where behavioural patterns could be observed. All six sample bottles were agitated

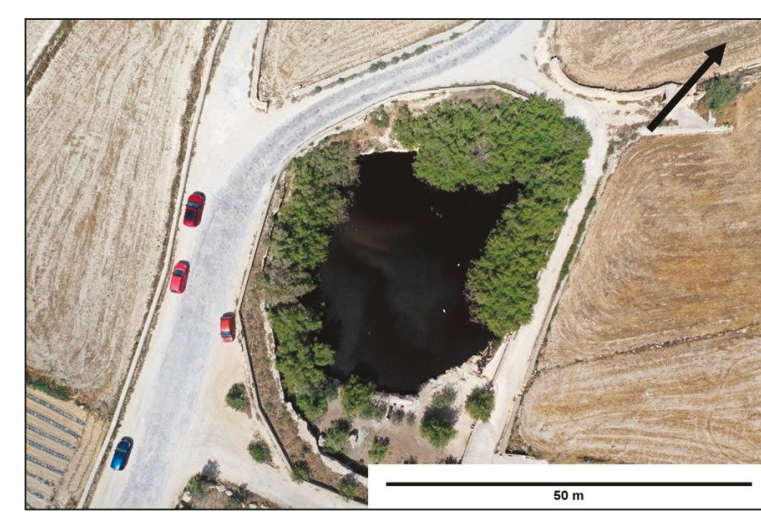

Figure 2. Aerial photo of L-Ghadira ta' Sarraflu (SRF) taken at $65 \mathrm{~m}$ above the water body. North is indicated by the black arrow. The scale is in the bottom right-hand corner.

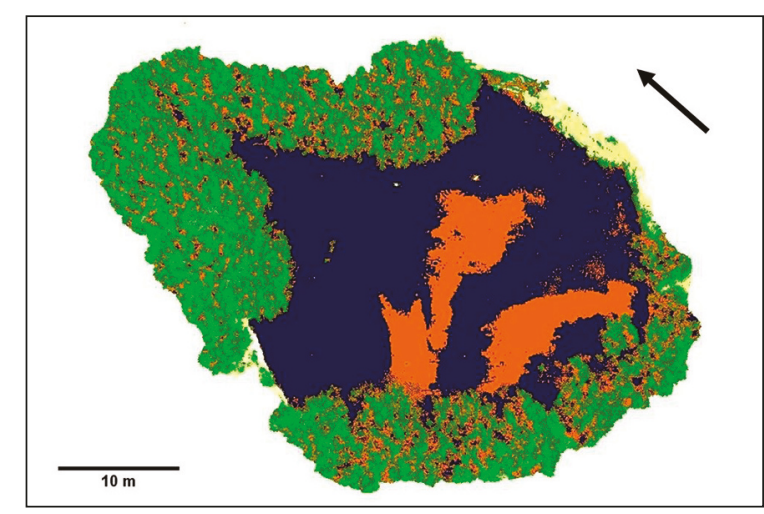

Figure 3. $k$-clustered pseudocolour image (PCI) with $k=6$ of L-Ghadira ta' Sarraflu (SRF) based on an aerial photograph taken from an altitude of $65 \mathrm{~m}$ above the water body. The orange patches in the water body indicate the extent of the discolouration. North is indicated by the black arrow at the top right, along with the scale at the bottom right.

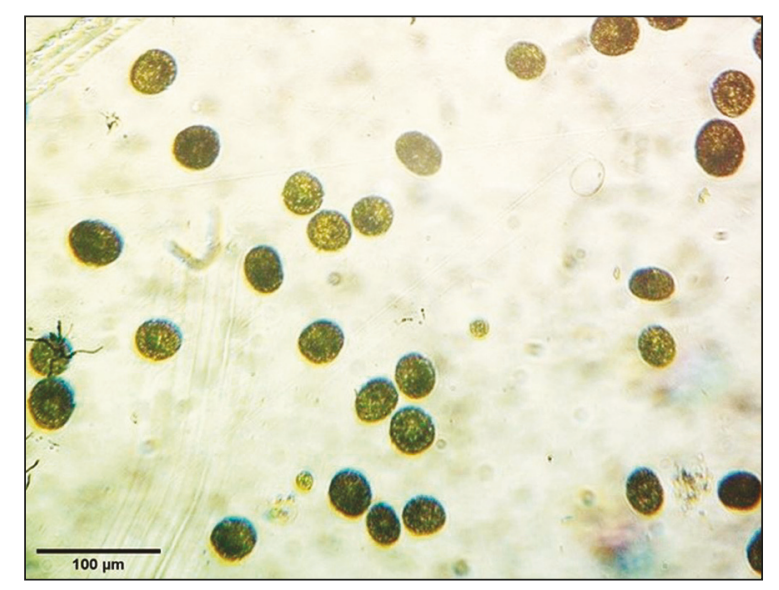

Figure 4. Peridinium cells photographed at x250 magnification with visible equatorial furrow in many cells. 
vigorously, and a water droplet from each was placed on a microscope slide. The live preparation was observed through an inverted microscope, to which a Swiftcam 10MP camera was attached. No staining or specialised optical procedures were carried out, to minimise disturbance to the organisms present. Flagella were not visualised directly, but their presence was inferred through the cells' patterns of movement. Further analysis of morphological characteristics was carried out at $\mathrm{x} 400$ magnification. The water in each of the six sample bottles was then fixed with Lugol's Iodine (Fig. 4), using the procedure recommended by Bellinger \& Sigee (2015).

Following fixation, the sample bottles were agitated vigorously, and two $5 \mathrm{~mL}$ subsamples pipetted out of each and placed in separate Petri dishes. Each Petri dish was observed through an inverted microscope at $\times 100$ magnification and 10 micrographs of the visual field were taken from random areas of each Petri dish (Fig. 5). A random sample of 1000 cells from the micrographs were subsequently processed in ImageJ to obtain data for cell dimensions and abundance. Dimensions were characterised by measuring cell diameters using the 'Measure' tool.

Automatic counting of cells was carried out following a 'training' phase, during which the size range and shape characteristics of the cells were determined. The 'training' data was subsequently used to identify and count cells in each image using the 'Analyze Particles' tool (Fig. 6).

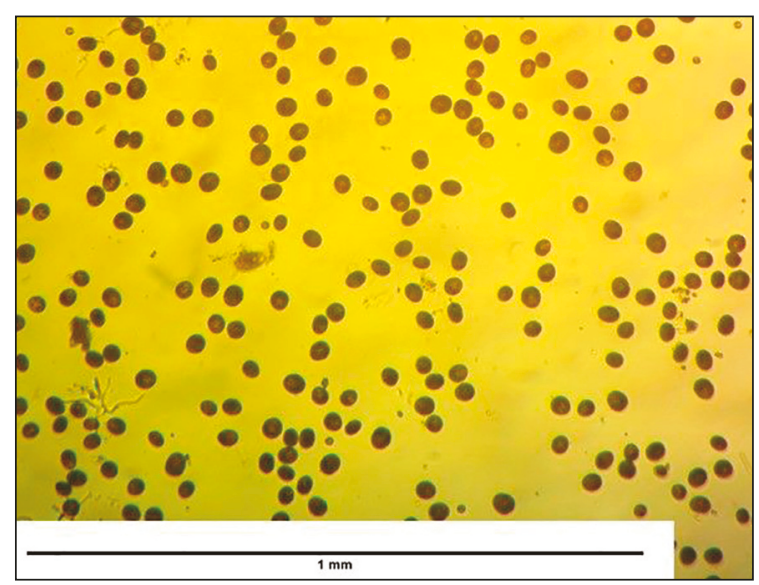

Figure 5. Micrograph at x100 magnification of Peridinium cells stained with Lugol's iodine, for processing in ImageJ to obtain cell diameters.

\section{Meteorological data}

The average air temperature for the period from $1^{\text {st }}$ March, to $31^{\text {st }}$ May were obtained from the Meteorological Office at Malta International Airport, situated approximately $33 \mathrm{~km}$ southeast of SRF. This was done to identify any trends or spikes in temperature that may have contributed to the bloom's formation.

\section{RESULTS}

The anomalous discolouration was mainly concentrated in two high-density plumes, covering approximately a quarter of the water surface at the time of survey. No discernible currents were present beyond surface-water agitation by a light breeze and by waterfowl.

\section{Physicochemical properties of pond water}

Figure 7 to Figure 10 compare the four water parameters (EC, $\mathrm{pH}, \mathrm{ORP}$ and $\mathrm{DO})$ measured at $\mathrm{SRF}$, with the authors' archive data for coastal and inland rainwater pools. This was done to place the pond in a broader context of rain-fed waterbodies situated ca. $30 \mathrm{~m}$ from the seashore, and several kilometres from the coast respectively. EC values for SRF ranged from $2615 \mu \mathrm{S} \mathrm{cm}^{-1}$ to $2663 \mu \mathrm{S} \mathrm{cm}^{-1}$ (mean: $2636.7 \pm 14.8 \mu \mathrm{S} \mathrm{cm}^{-1}$ ) and were found to be much higher than those of the coastal and inland pools

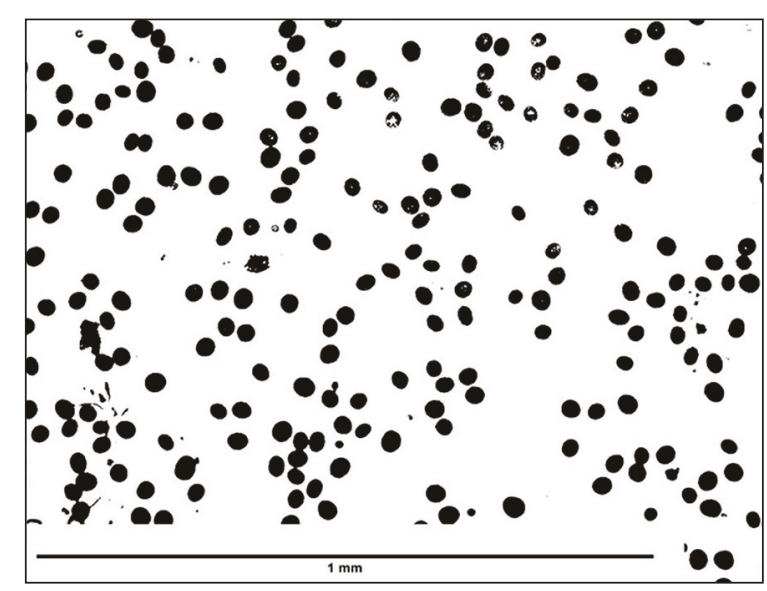

Figure 6. Micrograph at x100 magnification of Peridinium cells stained with Lugol's iodine following image processing training phase in ImageJ for cell enumeration. 


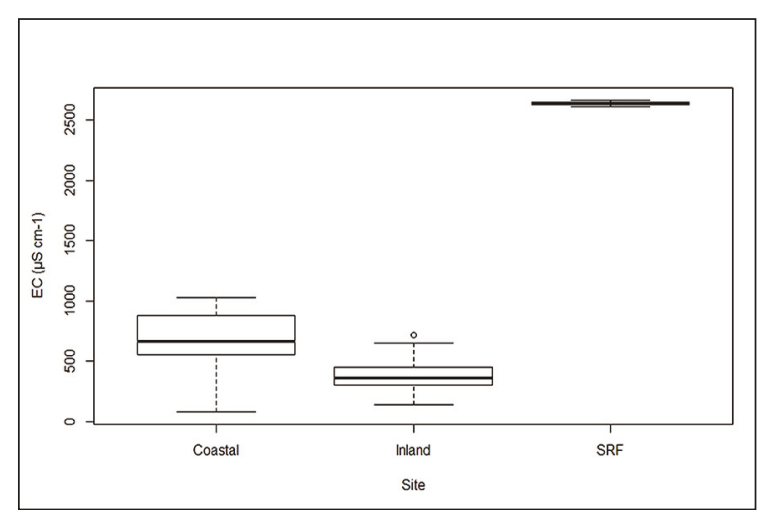

Figure 7. Relative variation of EC of pond water at L-Ghadira ta' Sarraflu (SRF) ranging from $2615 \mu \mathrm{S} \mathrm{cm}^{-1}$ to $2663 \mu \mathrm{S} \mathrm{cm}$ ${ }^{1}$ (mean: $2636.7 \pm 14.8 \mu \mathrm{S} \mathrm{cm}^{-1}$ ), compared with coastal pools $\left(689.7 \pm 244.2 \mu \mathrm{S} \mathrm{cm}^{-1}\right)$ and inland pools $(383.5 \pm 161.6 \mu \mathrm{S}$ $\left.\mathrm{cm}^{-1}\right)$. Comparative data from coastal and inland wetlands collected by the authors during April and May 2020.

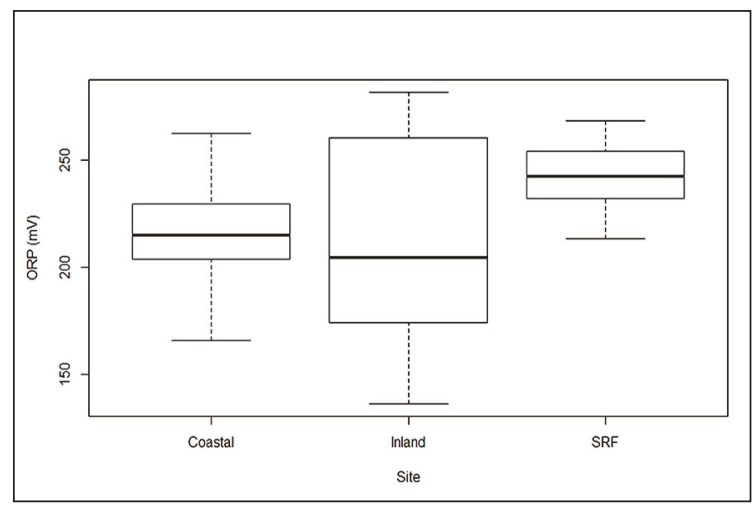

Figure 9. Relative variation in Oxidation-Reduction potential (ORP) of pond water at L-Ghadira ta' Sarraflu (SRF) $(242.38 \pm 16.9 \mathrm{mV})$ compared with that recorded from coastal pools $(215.50 \pm 23.59 \mathrm{mV})$ and inland pools $(211.67$ $\pm 47.87 \mathrm{mV}$ ). Comparative data from coastal and inland wetlands collected by the authors during April and May 2020.

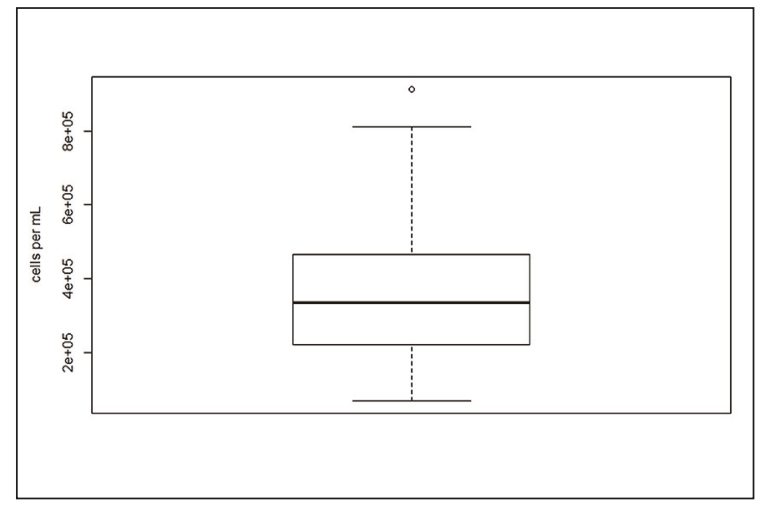

Figure 11. Variation of the concentration of Peridinium cells across samples. Mean density: $358118 \pm 165227$ cells $\mathrm{mL}^{-1}$.

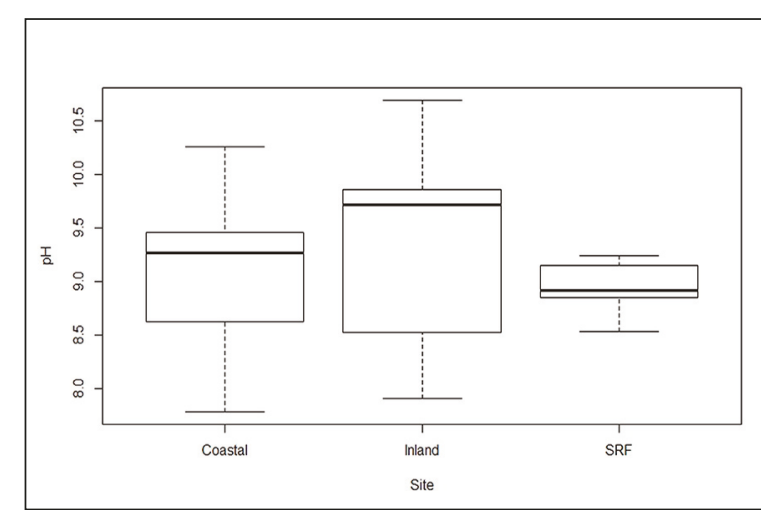

Figure 8. Relative variation in $p H$ of pond water at LGhadira ta' Sarraflu (SRF) ranging from 8.54 to 9.24 (mean: $8.95 \pm 0.24)$ compared with coastal pools $(9.23 \pm 0.61)$ and inland pools $(9.34 \pm 0.87)$. Comparative data from coastal and inland wetlands collected by the authors during April and May 2020.

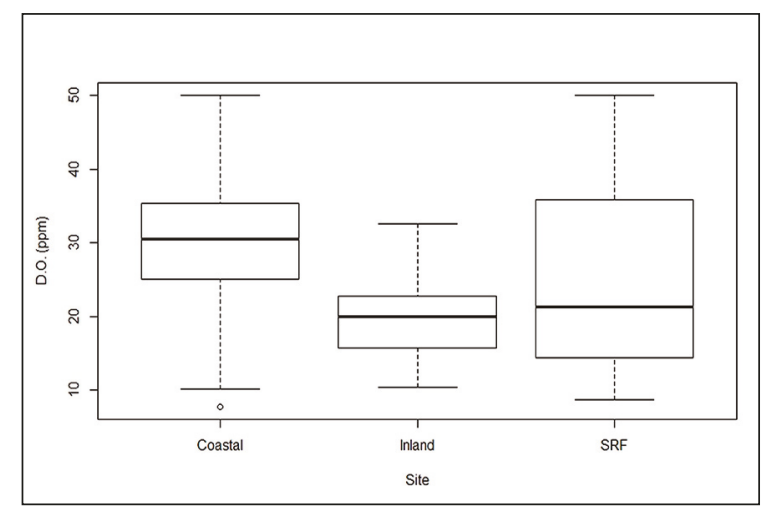

Figure 10. Relative variation in the dissolved oxygen (DO) concentration (ppm) of pond water at L-Ghadira ta' Sarraflu (SRF) $(25.30 \pm 14.30 \mathrm{ppm})$ compared with that recorded from coastal pools $(31.20 \pm 12.82 \mathrm{ppm})$ and inland pools $(19.53 \pm$ $5.66 \mathrm{ppm})$. Comparative data from coastal and inland wetlands collected by the authors during April and May 2020.

(Fig. 7). As a result, the EC range for SRF was found to be outside the range for "freshwater" given by the United States Geological Survey (USGS), and well within the "brackish-water" category. While the mean $\mathrm{pH}$ at SRF was found to be lower than the coastal and inland pools (Fig. 8), the mean ORP at SRF was higher (Fig. 9). Mean DO data from SRF however was comparable with that recorded from the coastal and inland pools (Fig. 10).

\section{Identification of phytoplankton}

Microscopic examination (x100) of unmodified pond water from SRF indicated a high-density 


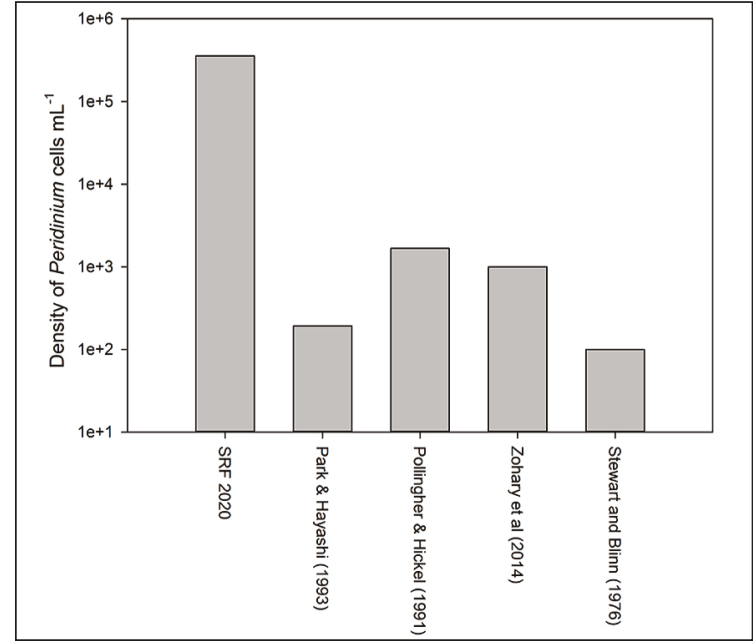

Figure 12. Comparison of the density in log scale of the Peridinium bloom at SRF with other blooms of the same genus recorded in literature. Bloom densities for Peridinium were obtained from Park \& Hayashi (1993), Pollingher \& Hickel (1991), Zohary et al. (2014) and Stewart \& Blinn (1976).

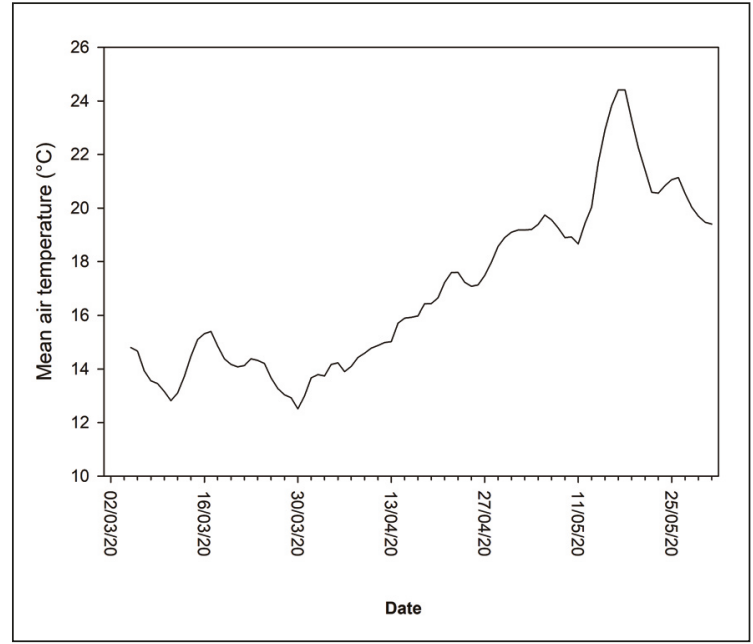

Figure 13. Mean air temperature $\left({ }^{\circ} \mathrm{C}\right)$ during the period $1^{\text {st }}$ March to $31^{\text {st }}$ May 2020 expressed as a five-day moving average.

unialgal assemblage of ovoid free-swimming cells. The algal cells were observed to move in a 'whirling' pattern suggestive of dinoflagellates. Further examination of live cells under higher magnification (x400) indicated a transverse furrow traversing the central area of each cell as well as numerous brown chloroplasts. The shape of the cells, the position of the equatorial furrow and the numerous chloroplasts were consistent with the general morphology of the genus Peridinium Ehrenberg, 1830. Cell diameters ranged from $11 \mu \mathrm{m}$ to $41 \mu \mathrm{m}$ (mean: $29.1 \mu \mathrm{m} \pm 5.54 \mu \mathrm{m}$ ), which were consistent with the size ranges for members of the genus in the literature (Carty, 2014; Cart \& Parrow, 2015; Moestrup \& Calado, 2018), and the configuration of the thecal plates was consistent with that of Peridinium cf. cinctum (O.F. Müller) Ehrenberg (Dinoflagellata Dinophyceae Peridiniaceae) (Kretschmann, 2020). Analysis of the micrographs also indicated the presence of other plankton in very low densities relative to the dinoflagellates, including rotifers and ciliates.

\section{Density of Peridinium}

The density of Peridinium cells per subsample ranged from 91 to 1185 cells, with an average of $465.3 \pm 214.7$ cells. This corresponded to $358118 \pm$ 165227 cells $\mathrm{mL}^{-1}$ as indicated in figure 11 . The density of the present bloom is put into context by comparing its cell density with that of other Peridinium blooms recorded in literature (Fig. 12).

\section{Temperature data}

The mean daily air temperature, as published by the Meteorological Office of Malta International Airport, showed a steady upward trend (Fig. 13) throughout April and early May 2020 (mean: $17.6 \pm$ $2.8^{\circ} \mathrm{C}$ ) relative to March 2020 (mean: $14.0 \pm 1.3^{\circ} \mathrm{C}$ ). The mean air temperature rose from $13.1^{\circ} \mathrm{C}$ on $3^{\text {rd }}$ April to $18.1^{\circ} \mathrm{C}$ on $30^{\text {th }}$ April, the day the bloom was first reported. It subsequently continued rising steadily, reaching $25.3^{\circ} \mathrm{C}$ on $15^{\text {th }}$ May 2020 . On the day of survey, the mean air temperature was $17.4^{\circ} \mathrm{C}$, whilst the mean temperature of the pond water, measured just below the surface, was $21.2 \pm 0.5^{\circ} \mathrm{C}$.

\section{DISCUSSION}

Aside from being the first recorded bloom from this wetland, the cell density of Peridinium and its contribution to the total phytoplankton was prominent enough to attract and maintain public attention for several days. The study found that the density of the bloom was approximately between 200 to 3500 times higher than in others reported in the literature for the same genus (Fig. 12). Such phyto- 
plankton density may however be a consequence of the restricted volume of SRF. As a result, the bloom cannot dilute with increasing distance from its origin as it would in a much larger body of water.

In the absence of previous records of blooms or water quality data for SRF, the underlying cause of the bloom could not be determined or placed into any meaningful context. Physicochemical parameters measured during the bloom therefore could not be compared against any mean values and variances as no baseline data was available. Consequently, only informed speculation could be drawn from the available data collected.

It should be noted that the mean air temperature increased steadily during the three weeks preceding the bloom and this was presumably also reflected in a corresponding rise in water temperature. Rapid increases in water temperature are known to be one of the possible drivers of algal blooms (Grigorszky et al, 2006) suggesting that this may have been a trigger for the SRF bloom. However, such temperature increases are part of an annual cycle, and they do not appear to have been accompanied by a bloom in previous years. The possibility that smaller, less detectable blooms did occur nonetheless exists.

The principal drivers of bloom events also include nutrient enrichment of pond water (Grigorszky et al, 2006). No information about the baseline nutrient status was available. Moreover, the nutrient levels of pond water during the bloom were not measured as the survey was carried out at a time when the Water Quality Laboratory at the University of Malta was not operational due to COVID-19 restrictions.

It is not known whether the Peridinium bloom at SRF was an isolated event as any previous blooms were either undetected or unreported. This highlights the need for a systematic monitoring programme of phytoplankton communities and water quality, as this would locate blooms such as this in a broader context and enable more effective management of this protected wetland.

\section{ACKNOWLEDGEMENTS}

The authors are grateful to Martina Cutajar for field and laboratory assistance, and to Therese Bellia DeGiorgio for laboratory assistance.

\section{REFERENCES}

Bellia A.F. \& Lanfranco S., 2019. A preliminary assessment of the efficiency of using drones in land cover mapping. Xjenza, 7: 18-27. https://doi.org/10.7423/ XJENZA.2019.1.02

Bellinger E.G. \& Sigee D.C., 2015. Freshwater algae: identification, enumeration and use as bioindicators. John Wiley \& Sons.

Carty S., 2014. Freshwater Dinoflagellates of North America, Ithaca: Cornell University Press. https: //doi.org/https://doi.org/10.7591/9780801470370

Carty S. \& Parrow M.W., 2015. The Dinoflagellates. In: Wehr J.D., Sheath R.G. \& Kociolek J.P. (Eds.), Freshwater algae of North America: ecology and classification. Elsevier.

Grigorszky I., Kiss K.T., Beres V., Bacsi I., Márta M., Mathe C., Vasas G., Padisak J., Borics G., Gligora M. \& Borbély G., 2006. The effects of temperature, nitrogen, and phosphorus on the encystment of Peridinium cinctum, Stein (Dinophyta). Hydrobiologia, 563: 527-535. https://doi.org/10.1007/s10750006-0037-z

Hughes T., Szmant A.M., Steneck R., Carpenter R. \& Miller S., 1999. Algal blooms on coral reefs: what are the causes? Limnology and Oceanography, 44: 15831586. https://doi.org/10.4319/lo.1999.44.6.1583

Kretschmann J., 2020. Diversity, morphology, and taxonomy of selected dinophytes. Unpublished Doctoral dissertation., Ludwig-Maximilians-Universität München.

Lanfranco S., Debono S., Borg J.A. \& Schembri P.J., 2018. Report on a phytoplankton survey in Maltese waters as a follow-up to a "mucilage event" in October 2016. University of Malta.

Moestrup Ø. \& Calado A.J., 2018. Süßwasserflora von Mitteleuropa, Bd. 6-Freshwater Flora of Central Europe, Vol. 6: Dinophyceae (Vol. 6). Springer-Verlag. https://doi.org/10.1007/978-3-662-56269-7

Park H.D. \& Hayashi H., 1993. Role of encystment and excystment of Peridinium bipes f. occulatum (dinophyceae) in fresh water red tides in lake Kizaki, Japan. Journal of Phycology, 29: 435-441. https:// doi.org/10.1111/j.1529-8817.1993.tb00144.x

Pollingher U. \& Hickel B., 1991. Dinoflagellate associations in a subtropical lake (Lake Kinneret, Israel). Archiv für Hydrobiologie, 120: 267-285.

Schneider C.A., Rasband W.S. \& Eliceiri K.W., 2012. NIH Image to ImageJ: 25 years of image analysis. Nature Methods, 9: 671-675. https://doi.org/10.1038/ nmeth.2089

Smayda T.J., 1997. What is a bloom? A commentary. Limnology and Oceanography, 42: 1132-1136. https:// doi.org/10.4319/lo.1997.42.5_part_2.1132

Stewart A.J. \& Blinn D.W., 1976. Studies on Lake Pow- 
ell. USA: Environmental factors influencing phytoplankton success in a high desert warm monomictic climate. Archiv für Hydrobiologie, 78: 139-164.

Thompson P.A., Bonham P.I. \& Swadling K.M., 2008.

Phytoplankton blooms in the Huon Estuary, Tasmania: top-down or bottom-up control? Journal of
Plankton Research, 30: 35-753. https://doi.org/10. 1093/plankt/fbn044

Zohary T., Sukenik A. \& Berman T., 2014. Chapter 11: Peridinium gatunense. In: Lake Kinneret, pp. 191212. Springer, Dordrecht. https://doi.org/10.1007/ 978-94-017-8944-8_11. 